Матеріали Всеукраїнської науково-практичної конференції «Актуальні питання діагностики, лікування, раціональної фармакотерапії, диспансеризації та реабілітації в практичі сімейного лікаря"

DOI

\title{
ВПЛИВ ДИНАМІЧНОЇ ЕЛЕКТРОНЕЙРОСТИМУЛЯЦІЇ НА ПОКАЗНИКИ ВІТАМІННОГО СТАТУСУ ПРИ ХРОНІЧНОМУ ПАНКРЕАТИТІ
}

๑Л. С. Бабінець, І. М. Галабіцька

ДВНЗ «Тернопільський державний медичний університет імені І. Я. Горбачевського МОЗ України»

Динамічна електронейростимуляція - це метод немедикаментозного лікування, заснований на впливі на активні рефлекторні зони і точки динамічними імпульсами електричного струму, форма яких постійно змінюється і залежить від величини електричного опору поверхні шкіри на піделектродній ділянці. При цьому позитивний ефект полягає не тільки у ліквідації болю, але і в дії на причину захворювання.

Мета роботи. Оцінити клінічну ефективність включення до комплексного лікування хворих на ХП з явищами гіповітамінозів курсу динамічної електронейростимуляції (ДЕНС).

Матеріали і методи. Було обстежено 79 амбулаторних пацієнтів з ХП у фазі стійкої або нестійкої ремісії. Діагноз ХП верифікували за загальноприйнятими стандартами. Вміст вітаміну С у плазмі крові визначали за методом Фармера. Визначення рівнів вітамінів В1 і В6 проводили флуориметричним методом за методикою В. Н. Букіна та $Є$. П. Скоробогатової, рівнів токоферолу та ретинолу - спектрофотометричним методом.

Пацієнтів із ХП поділили на дві групи за програмами корекції: I група (42 хворих) отримувала загальноприйнятий у гастроентерології лікувальний комплекс (ЗЛ), ІІ група (37 хворих) - ЗЛ комплекс, посилений використанням курсу динамічної електронейростимуляції, що включав 12-14 сеансів за запропонованою схемою. Лікування проводили ДЕНС-апаратом, використовуючи вбудований терапевтичний електрод. Обробляли такі ділянки: зона прямої проекції больових відчуттів (індивідуально у кожного хворого) та прямої про- екції підшлункової залози (епігастральна ділянка) на частоті 77 Гц, зона сегментарного кільця на рівні 6-8 грудних сегментів на частоті 60 Гц 3-5 разів, замикаючи коло, попереково-крижова зона на частоті 20 Гц. Вплив проводився лабільним методом у режимі «терапія" в комфортному енергетичному діапазоні ЕД 2 по 5 хв на кожній ділянці. Після двох аналогічних курсів лікування протягом року виконували контрольне дослідження.

Результати дослідження. Було встановлено наявність у хворих на ХП після проведеного лікування достовірної динаміки досліджуваних показників у II групі після лікування стосовно таких у I групі: аскорбінова кислота: (I група - $(6,81 \pm 0,85)$ проти $(7,32 \pm 0,53)$ мг/л у II групі), ретинолу (I група - $(1,02 \pm 0,11)$ проти $(1,32 \pm 0,12)$ мкмоль/л), токоферолу (І група - $(76,57 \pm 11,09)$ проти $(89,32 \pm 5,21)$ мкмоль/л), тіаміну $((0,034 \pm 0,005)$ проти $(0,038 \pm 0,001)$ мкмоль/л), піридоксину $((0,102 \pm 0,006)$ проти $(0,143 \pm 0,005)$ мкмоль/л) $(p<0,05)$.

Висновки. Було достовірно встановлено позитивну динаміку в обох групах пацієнтів після проведеного курсу терапії, проте у пацієнтів, які отримували додатково курс ДЕНС, лікувальний ефект був вагомішим: рівень аскорбінової кислоти став вищим на 6,97 \% після лікування у II групі у порівнянні з І, рівень тіаміну - на 10,53 \%, піридоксину - на $28,68 \%$, ретинолу - на $22,73 \%$, токоферолу - на 14,28 \%. Отже, курс ДЕНС за запропонованою схемою сприяє достовірному регресу дефіциту досліджуваних вітамінів, через запуск каскаду регуляторних і адаптаційних механізмів організму. 